Article

\title{
Artisanal and Small-Scale Gold Mining in Syanyonja, Busia Gold District, South Eastern Uganda: Impacts on the Mining Population and the Environment
}

\author{
Timothy Omara ${ }^{1,2^{*}}$, Shakilah Karungi ${ }^{3}$, Stephen Ssebulime ${ }^{4}$, Kibet Mohamed Kiplagat ${ }^{5}$, \\ Ocident Bongomin $^{6}$, Remish Ogwang ${ }^{7}$, Solomon Akaganyira ${ }^{8}$ \\ ${ }^{1}$ Department of Chemistry and Biochemistry, School of Biological and Physical Sciences, Moi University, \\ Uasin Gishu County, Kesses, P.O.Box 3900-30100, Eldoret, Kenya. \\ ${ }^{2}$ Department of Quality Control and Quality Assurance, Product Development Directory, AgroWays Uganda \\ Limited, Plot 34-60, Kyabazinga Way, P.O.Box 1924, Jinja, Uganda. \\ ${ }^{3}$ Department of Mining and Water Resources Engineering, Faculty of Engineering, Busitema University, \\ P.O.Box 236, Busitema, Tororo, Uganda. \\ ${ }^{4}$ Directorate of Government Analytical Laboratory, Ministry of Internal Affairs, Plot No. 2, Lourdel Rd, \\ Wandegeya, P.O.Box 2174, Kampala, Uganda. \\ ${ }^{5}$ Department of Mechanical Engineering, School of Engineering, Moi University, Uasin Gishu County, \\ Kesses, P.O.Box 3900-30100, Eldoret, Kenya. \\ ${ }^{6}$ Department of Manufacturing, Industrial and Textile Engineering, School of Engineering, Moi University, \\ Uasin Gishu County, Kesses, P.O.Box 3900-30100, Eldoret, Kenya. \\ ${ }^{7}$ Department of Quality Control, Rene Industries Limited, P.O.Box 6034, Kampala, Uganda. \\ 8 Department of Mechanical Engineering, Faculty of Engineering and Architecture, American University of \\ Beirut, P.O. Box 11-0236, Riad El-Solh 1107 2020, Beirut, Lebanon.
}

*prof.timo2018@gmail.com, omara.timothy@students.mu.ac.ke, timothy.omara@agroways.ug

\begin{abstract}
Syanyonja village in the gold district of Busia, South East of the Republic of Uganda contain geologically epigenetic gold quartz vein deposits in carbonate-altered mafic metavolcanic rocks, deposited as quartz reefs in mineralized shear zones. In supracrustal rocks, alluvial gold is obtained from weathered auriferous quartz veins, which are of late orogenic granitic activity. The Syanyonja gold deposits have long been subjected to artisanal and small-scale gold mining (ASGM) by the locals for livelihood. This study determined the amount of mercury discharged with tailings into Namukombe stream, a major water body in Syanyonja village and investigated the impacts of ASGM on the mining population and the environment. Quantitation of mercury discharged with tailings was done by mass balance method. Field survey at the mining sites was done followed by administration of questionnaires to 50 stampeders in the village. The study indicates that about $8 \%$ of mercury mixed with auriferous materials are lost in tailings, accounting for an annual mercury release of about $1.757 \mathrm{~kg}$ into the environment. Socio-demographic results indicate that the majority of the mining population (64\%) are male and ASGM have left health and environmental footprints, which directly or indirectly affects the population. The most common health problems among miners are malaria (36\%) and abdominal pain $(20 \%)$. The standard of living of the miners are evidently low, and most mines are characterized by school dropouts, prostitutes and thieves. Mining sites have deplorably poor hygiene, with evident burning of amalgams to recover gold. ASGM have been accompanied by wanton mowing down of vegetation, land degradation as well as mercuric pollution of water, air, land and aquatic ecosystems. It is suggested that the Ugandan government should re-enforce committees to follow up on ASGM activities, train artisans on sustainable gold mining using borax, magnets, sluice boxes as well as take up farming actively as an alternative.
\end{abstract}

Keywords: artisanal gold mining; Busia; environmental impacts; mercury pollution; Namukombe stream; panning; Syanyonja; Uganda. 


\section{Introduction}

Uganda is a low income landlocked African country with an averagely solid economic growth and demonstrated ambitions to attain a middle income status by 2020 [1]. The country is at a juncture in its history of economic transformation preceding a decade of an apogee of gross domestic product (GDP) growth that calamitously dwindled from 7\% in 2009 to 3.9\% in the fiscal year 2016/2017 [2, 3]. Accordingly, the fiscal policy is badly advocating for capital investment to revitalize this GDP. The minerals sector, which used to be informal and largely illegal, is poised to contribute a pivotal part in this economic move, as evidenced by its position of citation in the second National Development Plan for 2015 to 2020 [1].

Uganda lies in the African plate, a continental crust rich in Precambrian rocks of Achaean and Lower Proterozoic to Middle Proterozoic geology [4]. Thus, it has a substantial geological potential for precious minerals including copper, cobalt, tungsten, beryllium, bismuth, uranium, limestone, phosphate, vermiculite, kaolin, bentonite, diatomite, gypsum, glass sands, salts, pozzolana, dimension stones, gemstones, gold and crude oil [1,4-6]. Artisanal and small scale gold mining (ASGM) has been reported in Ugandan gold districts of Mubende (Kamalenge and Kisita), Kabale (Chiruruma, Chilima, Bugarama, Mugyera), Kisoro (Murindi, Mpororo, Rubuguri and Karamba), Namayingo, Bugiri, Mayuge, Busia (Tiira, Syanyonja, Makina, Amonikakinei), Buhweju (Kahengyere and Muti), Rukungiri (Bikongozo valley), Bushenyi (Mashonga in Kyamuhunga), Mbarara (Kitaka), Ibanda, Kanungu (Kashenyi, Kanungu, and Muramba), Moroto (Rupa, Katikikele and Kamalera), Abim (Alarek and Morulem), Nakapiripirit (Acherer), Kaabong (Lopedo, Sokodo, Kanguoth, Lemoyne, Nakapiril-Kekuli and Lugoto), Nakapiripirit, Hoima (Kafu River) and Amudat (Karita) [4, 7, 8]. Except in Kisita, Kamalenge, Tiira and Amonikakinei where gold is recovered from reefs (hard rock), gold is often recovered from alluvial auriferous materials, with Busia being the pioneer gold mining district $[4,6]$.

The Ugandan government recently accorded artisanal mining greater cognizance through its prominent inclusion in a draft of the National Mining and Minerals Policy. This initiative is believed shall establish the basis for the upcoming mining laws and regulations and related strategies and actions by the government. In view of the foregoing, more robust evidence of the significance of artisanal mining and clarity on the opportunities and challenges presented by the sector are needed.

Busia have underground workings and surface mining of both alluvial and hard rock gold ores. The principle livelihood activities in this area include trade (as it is at the border with Kenya), gold mining and agriculture [9]. Up to 600 vulnerable people of Buteba, Sikuda and Busitema sub-counties in Busia subsist on ASGM. A demographic ratio of 4:1 (men to women) was reported, with individual annual earnings estimated at 17 million Uganda shillings [10].

Globally, the upsurge of ASGM and the growing awareness of the negative impacts of mercury use, both in terms of environmental and human health, has culminated in the drafting and ratification of the Minamata Convention which constrain signatories to phase out mercury use. As a contribution to decision making, this study evaluated the impacts of mercury-based ASGM on the environment and a mining population in Uganda, taking evidence from Namukombe stream and its propinquity (Syanyonja village) as an example due to the intermittent ASGM in this area.

\section{Materials and Methods}

\subsection{Brief Description of the Study Area}

The study was conducted in Syanyonja village, Syanyonja Parish, Busitema subcounty, Samia Bugwe constituency, Busia gold district, South East of the Republic of Uganda. The choice of this area is explained by the high intensity of mercurial ASGM in it. Busia lies between $33^{\circ} 05^{\prime} \mathrm{E} 00^{\circ} 10^{\prime} \mathrm{N}$ and $34^{\circ} 01^{\prime} \mathrm{E} 00^{\circ} 35^{\prime} \mathrm{N}$ [6], covering an expanse of about $730.9 \mathrm{~km}^{2}$ of land. It is flanked by Tororo district to the North, Kenya to the East, Lake Victoria to the South, Namayingo district to the Southwest and Bugiri district to the West [6]. Busia comprises of a mixture of auriferous hard rock $(70 \%)$ and $30 \%$ alluvial soil which are part of the Cretaceous to Miocene intrusive alkaline carbonatite complexes of the Ugandan frontier with Kenya [4]. Namukombe stream, a tributary of River Malaba is one of the 
water bodies in Syanyonja village characterized by mercury based ASGM activities [6] and was of interest in this study.

\subsection{Apparatus Used}

A calibrated Mettler PM200 analytical balance (Marshall Scientific, Hampton, USA), retort, single use disposable hand gloves, dust masks and eye googles.

\subsection{Ethical Approval}

This research required no ethical approval. However, field studies were approved by Department of Mining and Water Resources Engineering, Faculty of Engineering, Busitema University, Tororo, Uganda (Approval No. BU/UG/2013/95).

\subsection{Determination of Amount of Mercury Discharged with Slurry Tailings}

Informal interviews with artisanal gold miners (stampeders) was conducted to assess the mercury losses during gold recovery. Mercury recovered after squeezing and panning the amalgams were estimated by mercury mass balance method described by preceding investigations $[11,12]$ as follows;

The mass of mercury (quicksilver) entering the system $(\mathbf{X} g)$ was measured using an analytical balance before being introduced into the amalgamation process to concentrate gold with heavier particles in a pan. The mass of the solid mercury-gold amalgam formed $(\mathbf{Y} g)$ and the amount of pure gold recovered $(\mathbf{Z g})$ were measured after amalgamation and panning respectively. The mass of mercury recovered after amalgamation (excess mercury), $\mathbf{M} g$ was determined as the mass of mercury recovered after squeezing the amalgam. The amalgam was burnt in open air on a retort to evaporate the mercury and then the solid was re-weighed and the mass noted.

The mass of mercury lost in the slurry tailings (discharged), D in grams was estimated from the difference in the masses of the mercury measured utilizing Equation 1.

$$
D=X-(Z-Y)-M
$$

The percentage of mercury discharged in slurry tailings was calculated from Equation 2.

$$
\% \text { discharged }=\frac{D}{X} \times 100
$$

The assumptions made were that no mercury was lost through evaporation during amalgamation and losses due to adsorption onto pan walls are negligible. The procedure was repeated using different masses $(2,3,4,5$ and $6 \mathrm{~g})$ of mercury which are typical of the quantities of mercury used for amalgamation at different ASGM sites in Syanyonja village.

\subsection{Collection of Field Data}

Direct field observation was done in the mining sites in order to appreciate the rate of environmental destruction and the various phases involved in mercurial ASGM. The fieldwork in Syanyonja village was conducted between April 2019 and June 2019. Stampeders (at least 18 years old with a seniority of at least 1 year and consenting) were selected. Because of the absence of an exhaustive list of stampeders working on the ASGM sites due to the intermittent nature of this activity, selection by simple random sampling was impossible. A quota sampling according to sex ( $1 / 3$ of women, $2 / 3$ of men) was performed considering the fact that approximately one-third of women work in ASGM sites [13]. To compensate for the selection bias associated with this type of sampling, the estimated size of the sample $(n=25)$ was doubled to 50 subjects to cover potential nonrespondents. In quantitative terms, the power of the target study was at least $75 \%$, sufficient in the event where less than $50 \%$ of the stampeders are unaware of the impacts of mercury use in ASGM on miners and the environment [14]. Individual interviews (face to face) was conducted basing on an anonymous, standardized questionnaire (Figure 1). The questionnaire captured socio-demographic 
characteristics, common illness in the area, number of family members engaged in ASGM, types and sources of proteinaceous food eaten, and source of water for domestic use (drinking) and for livestock.

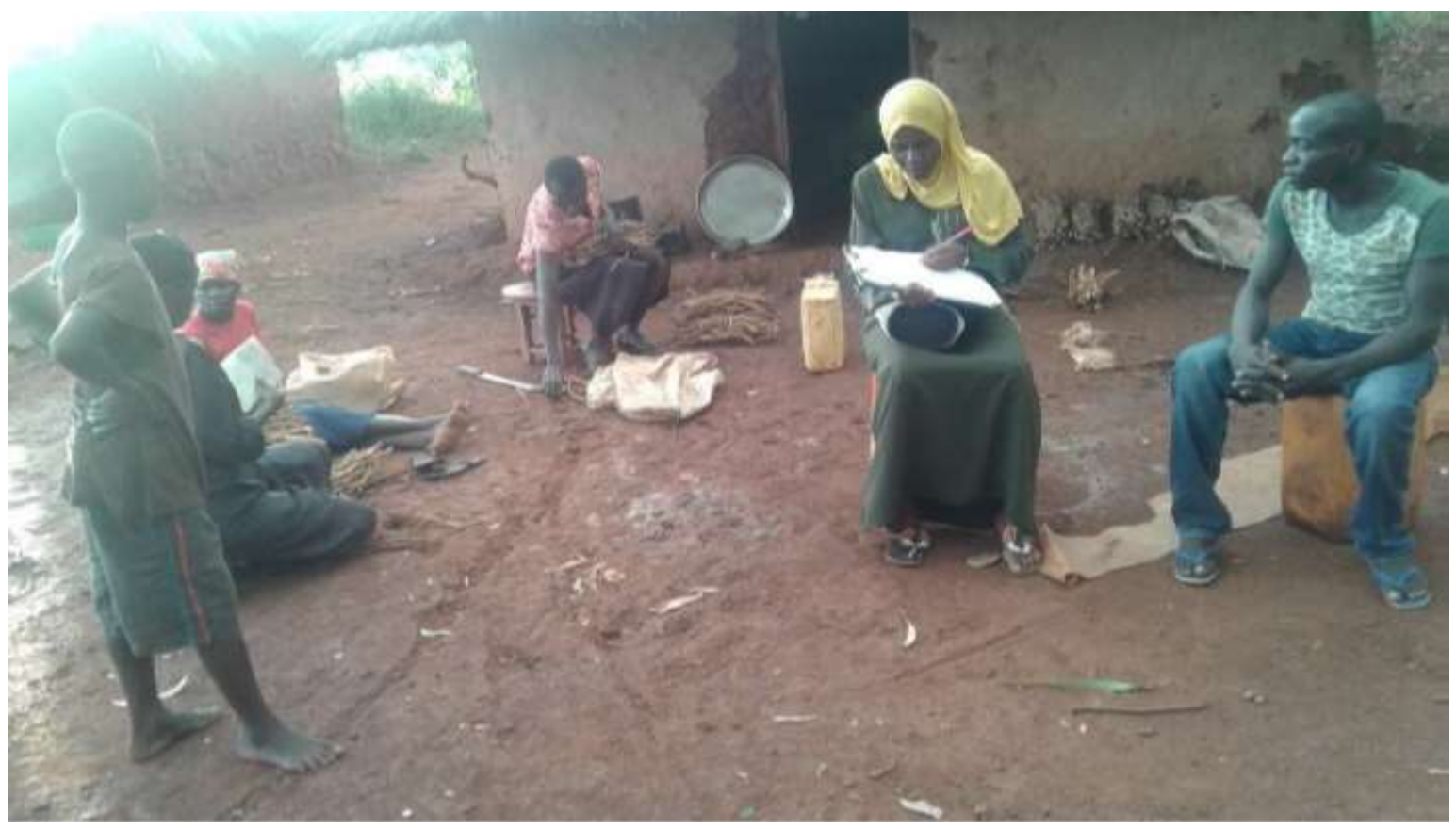

Figure 1. Administration of questionnaires in Syanyonja village (photo used with verbal permission from the interviewed household).

\subsection{Statistical Analysis of Results}

All data collected in this study were entered into Microsoft Excel for Office 365 (version 16, Microsoft Corporation, USA). Statistical analyses (One-way ANOVA, averaging and other descriptive statistics) were done using Minitab statistical software (Version 17, Minitab Inc., USA). Statistical significance was set at $p=0.05$.

\section{Results and Discussion}

\subsection{Mercury Lost in Slurry Tailings}

The results of mercury discharged with tailings are given in Table 1.

Table 1. This is a table. Tables should be placed in the main text near to the first time they are cited.

\begin{tabular}{lllll}
\hline $\begin{array}{l}\text { Mercury added, } \\
\mathbf{~}(\mathbf{g})\end{array}$ & $\begin{array}{l}\text { Mass of amalgam } \\
\text { formed, } \mathbf{Y}(\mathbf{g})\end{array}$ & $\begin{array}{l}\text { Mass of } \\
\text { recovered, } \mathbf{Z}(\mathbf{g})\end{array}$ & $\begin{array}{l}\text { Mass of mercury recovered } \\
\text { after amalgamation, } \mathbf{M}(\mathrm{g})\end{array}$ & $\begin{array}{l}\text { Mass of mercury lost } \\
\text { in tailings, } \mathbf{D}(\mathbf{g})\end{array}$ \\
\hline 1 & 0.36 & 0.13 & 0.51 & 0.26 \\
2 & 1.24 & 0.22 & 0.70 & 0.28 \\
3 & 2.34 & 0.30 & 0.69 & 0.27 \\
4 & 3.45 & 0.36 & 0.63 & 0.28 \\
5 & 4.39 & 0.40 & 0.71 & 0.30 \\
6 & 5.51 & 0.42 & 0.62 & 0.29 \\
$3.5 \pm 1.871$ & $2.88 \pm 1.94$ & $0.31 \pm 0.11$ & $0.64 \pm 0.08$ & $0.28 \pm 0.14$ \\
\hline
\end{tabular}

${ }^{1}$ Results in this row are means of the corresponding columns with standard deviations attached. 
About $8 \%$ of mercury used in amalgamation is discharged into the environment through slurry tailings during gold processing in Syanyonja and this poses a great threat to the environment. According to the interviewed mercury sellers around the mining sites, an average of $60 \mathrm{~g}$ of mercury is sold and used daily, implying that $4.8 \mathrm{~g}$ and 1,756.8 $\mathrm{g}$ of mercury are discharged into the slurry tailings daily and annually respectively. A report [13] indicated that about $58 \%(n=118)$ of sampled gold stampeders in a study done in Mubende and Busia gold districts of Uganda use about 1-50 g of mercury per person weekly. This computationally translates into 2,800 g per stampeder per year. The results of this study is in complete agreement with the anecdotal finding of COWI [15], which observed that, although there are no recent estimates on the use of mercury for ASGM in Uganda, the mean mercury consumption per miner from Busia and Mubende gold-mining sites could give a mercury consumption rate of about 40.5 tonnes per year. This is further substantiated by an estimate which indicated that approximately 1,400 tons of mercury are used every year by ASGM miners globally [16]. In Rwamagasa ASGM area located in Geita district of Tanzania, about $27 \mathrm{~kg}$ of mercury was estimated to be released to the environment yearly, with about $12 \mathrm{Kg}$ of gold recovered from the process [17]. It is equally likely that the amount of mercury lost to the slurry tailings is re-emitted to the atmosphere on a relatively short time scale of one to several years as the tailings are accumulated in above-the-ground piles and later reprocessed. It should therefore be over emphasized that the population living near to or downstream of Namukombe stream and the ASGM sites are at risk of mercury pollution [6].

\subsection{Socio-Demographic Characteristics and Exposure to Mercury}

A total of 50 stampeders were contacted in this study. The characteristics of the participants are given in Table 2 . The average age of the respondents was 26 years. The sample consisted of $64 \%$ men $(n=32)$ and $36 \%$ women $(n=18)$. There was no significant difference $(p=0.05)$ in the number of people who had stayed for 1 to 5 years and over 16 years in Syanyonja village (Table 2). Most of the family members of the respondents $(80 \%)$ were either directly or indirectly involved in mercury based ASGM. The gold mines are dominated by people between 20 years and above (70\%) though children (stampeders below 18 years of age) constituted about $14 \%$ of the mining population (Table 2). Overall, the levels of child labour were higher in ASGM sites that are more informal and where participation is poverty rather than enterprise driven. Some of the children in these mines are orphans, are from child-led households or lack school fees and scholastic materials, corroborating preceding studies in other parts of Uganda [7, 18]. This study also agrees well with previous reports that women realize fewer benefits from artisanal and small-scale mining than men but bear the brunt of negative impacts [7, 19-22].

In addition, the mines consist of people of various ethnic origins namely: Bagishu, Basoga, the Iteso, Karamojong (Karimojong) and the Congolese. This is similar to a report [7] which cited that Acherer, an ASGM site in Karamoja region (Nakapirpirit district) hosts different ethnic groups: the Iteso, Western Ugandans and Rwandese during peak periods of ASGM. It is known that decentralization, economic turmoil, the ten-fold gold price increase within the period of 1996 to 2002 coupled by prospects of improved livelihoods from ASGM attracts unemployed people to engage in ASGM [7, 20, 23].

In terms of exposure, the findings indicated that most respondents $(50 \%, n=25)$ had spent 31 years or more using mercury, most of which $(68 \%, n=17)$ were women. In a similar cross-sectional study in some sites of Mubende and Busia districts of Uganda, it was reported that $44 \%(n=90)$ of the respondents had used mercury for ASGM for 1 to 4 years while the remaining percentage $(56 \%$, $n=114$ ) had lived for 5 to 29 years handling ASGM mercury [13].

Pertaining health, it was noted that malaria (36\%) and abdominal pain (20\%) tops the list of the illnesses reported in the last two (2) years (Table 2). This could be because pits left after harvesting auriferous rock materials holds stagnant water which act as breeding grounds for female anopheles' mosquitoes, the plasmodium vector which enhances the spread of malaria-causing plasmodium $(P$. falciparum and P. malariae). Abdominal pains are probably due to the manual nature of ASGM in Syanyonja which involves digging, crushing and panning of auriferous materials, usually involving 
bending for long hours in scorching sun [6]. Gold artisans in Syanyonja employ rudimentary methods of gold extraction including panning [6], typical of other ASGM sites in Uganda [18, 20, 21] (Fig. 2). Human health problems, diseases and neuropsychiatric disorders such as malaria, cholera, venereal diseases (HIV/AIDS, gonorrhea, syphilis), musculoskeletal disorders (upper and lower limbs, back), sleep disruption (insomnia), headache, anorexia, tremor of the fingers, loss of fecundity, and abnormal fatigue have been reported in other ASGM communities [7, 24-26].

Table 2. Characteristics of the sampled respondents $(n=50)$.

\begin{tabular}{|c|c|c|c|}
\hline Variable & Categories & Number & Percentage \\
\hline \multirow{3}{*}{ Sex } & Male & 32 & 64 \\
\hline & Female & 18 & 36 \\
\hline & $1-5$ years & 22 & 45 \\
\hline \multirow{3}{*}{ Residence time in Syanyonja village } & 6-10 years & 04 & 7 \\
\hline & $11-15$ years & 02 & 3 \\
\hline & Over 16 years & 22 & 45 \\
\hline \multirow{2}{*}{ Family members engaged in ASGM } & Yes & 40 & 80 \\
\hline & No & 10 & 20 \\
\hline \multirow[t]{6}{*}{ Age of stampeders engaged in ASGM $^{1}$} & $1-10$ years & 04 & 8 \\
\hline & 10-15 years & 03 & 6 \\
\hline & $15-20$ years & 08 & 16 \\
\hline & 20-30 years & 10 & 20 \\
\hline & 31 years and over & 25 & 50 \\
\hline & None & 16 & 32 \\
\hline \multirow[t]{3}{*}{ Major sicknesses in the last 2 years } & Malaria & 18 & 36 \\
\hline & Acute respiratory problems & 02 & 4 \\
\hline & Abdominal pain & 10 & 20 \\
\hline
\end{tabular}

${ }^{1}$ Ages cited were from averaged information provided by the respondents in regard to their family members engaged in ASGM.

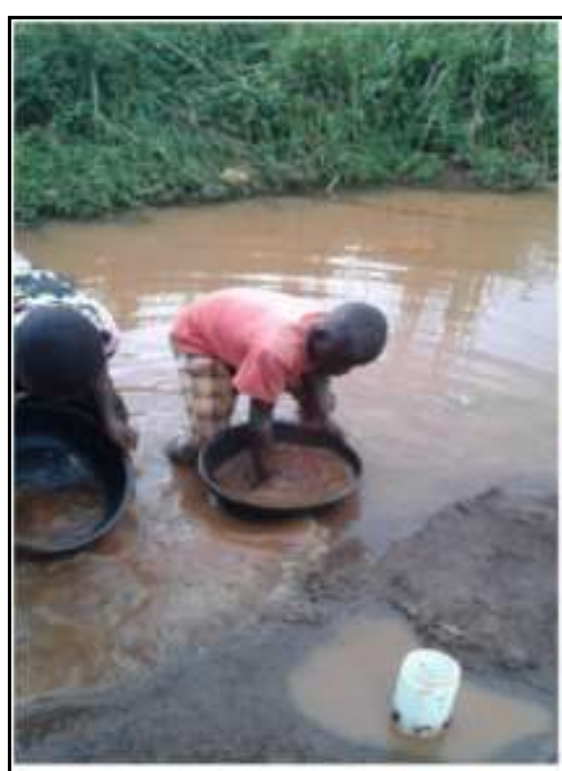

(a)

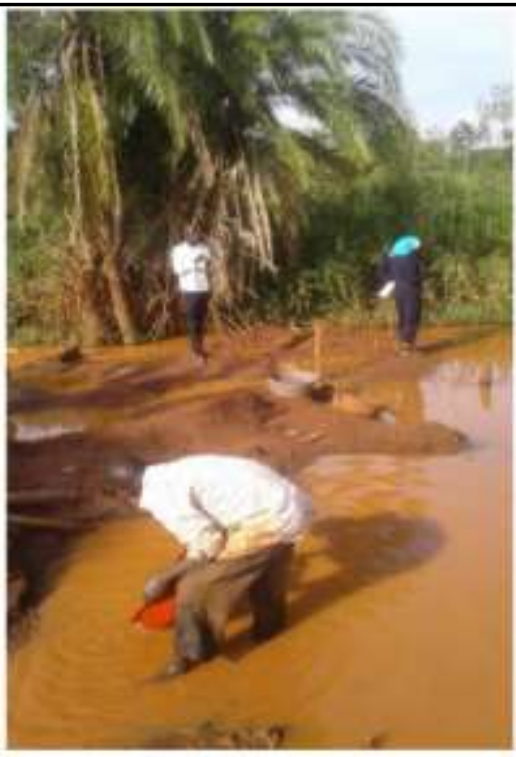

(b)

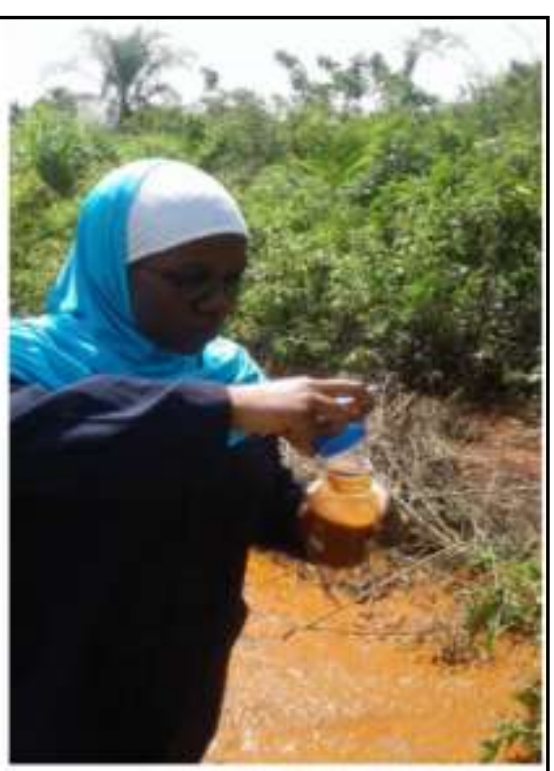

(c)

Figure 2. Panning of alluvium along Namukombe stream : (a) by children (school dropouts). Notice the plastic tin used for storing recovered gold nuggets; (b) by a man. Notice the ditches created; (c) quality of water from the stream. Notice the destruction of shrubs in the right background (modified from [6], photos reproduced with permission).

It was noted that in mines in Syanyonja, women are multitasked. They actively engage in ore processing and transportation, water collection, catering, prostitution, operate clinics amongst others. 
Unfortunately, this pivotal role played by women are not anywhere recognized in official ASGM policies [27] and in some cases they end up being victims of rape [18]. Also, ASGM is combined with domestic and reproductive work as well as small scale farming. Most women and girls are involved in low paying jobs, as most high paying opportunities are usually work prohibited by cultural norms for females to do. Therefore, women usually end up in panning, collecting water, transporting auriferous rock materials for crushing and burning of mercury in open air. Some operate eateries, sell airtime and consumables (such as waragi, cigarettes, cakes) around the mines. This is corroborant with preceding studies elsewhere in Uganda [7, 18, 21, 27].

Children are taken to the mining sites and this may expose them to atmospheric mercury vapour resulting from burning of mercury in open air. Inhalation of mercury vapours results in high blood concentration of mercury which are implicated for many respiratory, neurologic, renal, immunologic, dermatologic and reproductive complications [28]. Human health impacts emanating from the utilization of mercury in ASGM have been reported in African countries of Benin [29], Burkina Faso [30], Ghana [31, 32] and Mali [33]. This is evidenced by elevated levels of mercury in human blood, hair, urine and breast milk [26, 34, 35].

ASGM is largely a poverty-driven activity, used as a coping mechanism with thousands of families engaging in the mining practice $[18,36]$. This unfortunately exposes the miners to dermal contact with mercury in the dredged sediments as well as mercury-contaminated water [6]. Like reported for other parts of Busia (Tiira and Amonikakinei) [37], Karamoja region [7, 18], Mubende and Buhweju [13, 20, 21], miners in Syanyonja village do not employ any form of personal protective equipment during mining activities. This could partly be due to lack of sufficient income to purchase them and lack of awareness on the dangers of mercury [21]. In addition, miners are also exposed to other heavy metals such as Copper, Lead and Chromium because these metals are naturally part of auriferous rocks as arseno-pyrite ( $\left.\mathrm{FeAsS}_{2}\right)$, Copper II Sulphide ( $\left.\mathrm{CuS}_{2}\right)$ and Iron (II) Chromium trioxide $\left(\mathrm{FeO} \mathrm{Cr}_{2} \mathrm{O}_{3}\right)[38,39]$. These metals are released into the tailings during gold processing. Mbonimpa [9] also reported the presence of heavy metals in samples of rocks and sediments taken from around Namukombe stream and other areas between River Solo and River Malaba in Busia gold district. It is worth noting that most of the respondents, as reported previously [13], have explicit fears regarding the health and ecological impacts of mercury usage in gold recovering, peculiarly on the risk of polluting food and water resources and losing fecundity.

\subsection{Sources of Water Used for Drinking, Domestic Use and Animal Husbandry}

In Syanyonja village, the weather pattern influences a household's choice of the main source of drinking and cooking water. Accordingly, more than half (55\%) of the respondents reiterated that they rely on both borehole and Namukombe stream water for drinking and cooking purposes when compared to using borehole water only (Figure 3). Many residents turn to the stream water when the dry season sets in and the boreholes are dry. Contamination of Namukombe stream, boreholes, springs and bottled water in Uganda are well documented [6, 40-45], and thus, the results of this study agrees well with studies which indicated that ASGM communities in Uganda have contaminated ecosystems supporting their livelihoods [6, 18, 46-48]. Water is an indispensable part of life on planet earth and the availability of sufficiently clean and safe water is an important aspect of a community [40].

\subsection{Sources of Food}

The various sources of food consumed in Syanyonja village are given in Table 4 . The major foods consumed are beef, fish, chicken yams, beans, maize and millet flour. A preceding study indicated that fish and yams harvested from Namukombe stream are polluted with mercury [6]. Fish is widely consumed in many parts of Uganda [37, 49,50] because it has high protein content, low saturated fat and also contains omega-3 fatty acids, calcium, phosphorus, iron, trace elements like copper and a fair proportion of the B vitamins known to support good health $[6,49,51,52]$. Besides the good health benefits of fish, there have been many reports on contamination of fish by carcinogenic chemicals in Uganda $[6,49,53,54]$. 


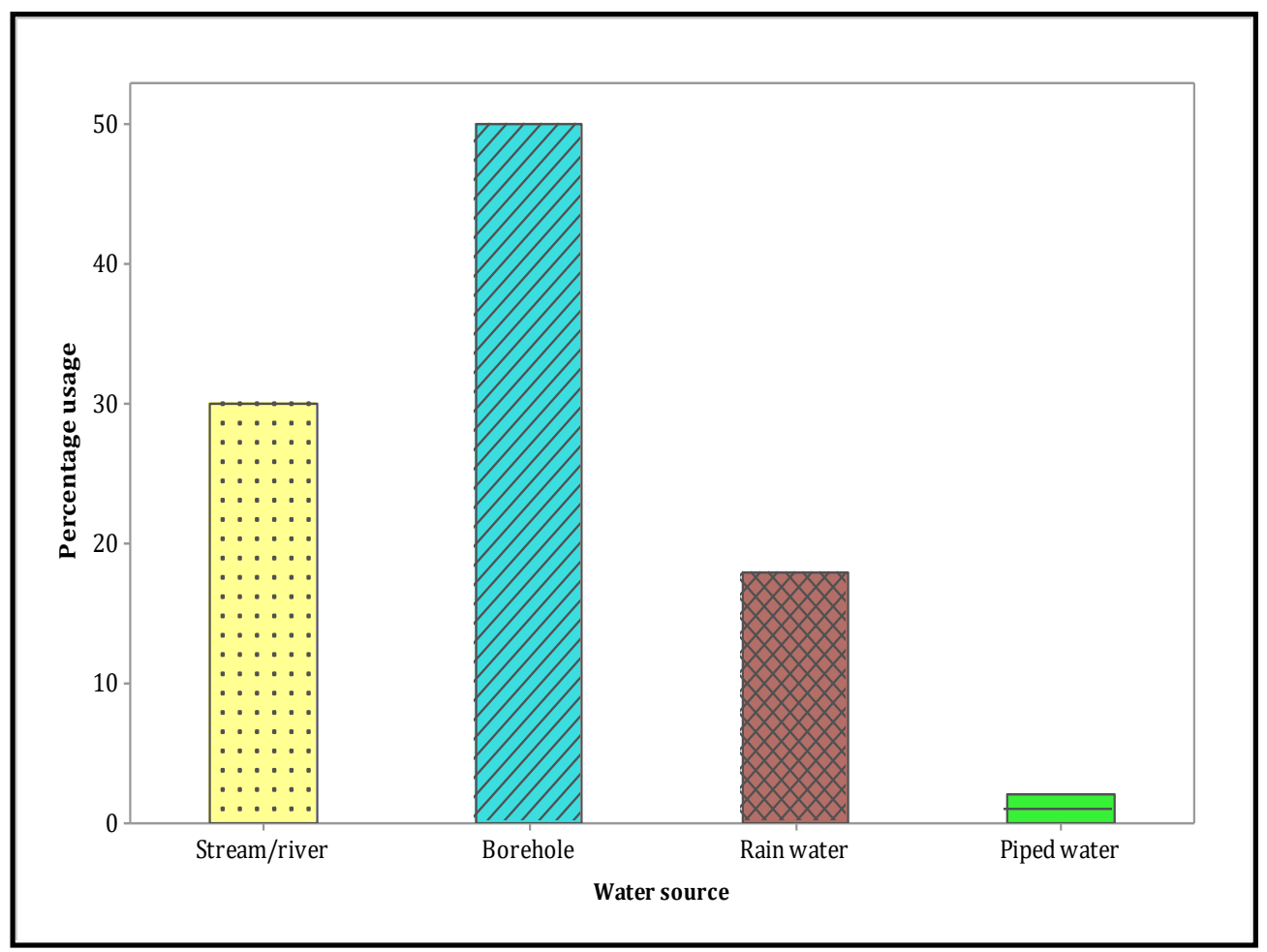

Figure 1. Major water sources used by residents of Syanyonja village

Table 4. Major sources of food for the sampled residents of Syanyonja village.

\begin{tabular}{llll}
\hline Variable & Categories & Frequency in a month & Percentage \\
\hline Major sources of proteins & Chicken & 02 & 10 \\
& Fish & 10 & 46 \\
& Beef & 12 & 41 \\
& Others (yams, beans, millet, e.t.c.) & 01 & 3 \\
Sources of fish consumed & Unknown & 11 & 44 \\
& Nearby market & 05 & 32 \\
& Namukombe stream & 08 & 4 \\
& Greater than 10 km from ASGM sites & 01 & 32 \\
Origin of yams consumed & Nearby market & 08 & 64 \\
& Namukombe stream and banks & 16 & 4 \\
\hline
\end{tabular}

Since most of the foods consumed by the community is from within the village, there is high chances that the locals are consuming mercury-contaminated foods and these risks are expected to be high if most of the fish are consumed whole, especially by children or pregnant women [6]. Other foods such as beef, milk and yams are equally unsafe as they can also get contaminated through water, food and atmospheric deposition of mercury.

\subsection{Impacts of ASGM on the Environment of Syanyonja Village}

Field observations and responses gathered reveal that the major environmental problems of ASGM mining in Syanyonja village are deforestation, land degradation, soil erosion, dumping of 
tailings, air and stream water pollution (Fig. 2). Deforestation will leave degraded and fragmented habitats for wildlife [55]. More so, this shall increase the vulnerability of forest ecosystems to invasive plant and animal species. Exposure of top soil may initiate soil erosion which when coupled with the open pits may lead to landslides [55].

Secondary impacts from erosion, including sedimentation and siltation are evident in Namukombe stream. Siltation reduces light penetration into water bodies, causing reduced photosynthetic activity in aquatic organisms as well as increased biochemical oxygen demand, clogging of fish gills thus death of aquatic organisms.

Wildcat pitting in many shallow pits and shafts across the mines were evident and these are excellent breeding grounds for mosquitoes and other disease vectors. In addition, the numerous small shafts and pits dispersed across the mines are hazards for livestock and humans (particularly children), who may fall in the pits, causing loss of lives, income and time. These observations have been reported in other ASGM sites of Uganda [7, 18, 48].

It was noted that some parts of Namukombe stream is experiencing siltation due to the cumulative effects of water-intense gold panning. This has greatly increased the turbidity of water from this stream (Fig. 2). Turbidity greater than 5 Formazin Turbidity Unit (FTU) indicate high levels of bacteria, pathogens or particles that can shelter harmful organisms from disinfection [40].

Land is a key denominator in food production and any economic development. Artisanal gold mining in Syanyonja is done on land that could otherwise be utilized for agriculture, which supports food security. Reluctancy to backfill open pits exacerbate the situation. The interviewed mining stampeders are incrementally phasing out agriculture and other livelihood enterprises for mining as an economic activity that will salvage them from poverty. It is known that ASGM cause environmental havocs in no small magnitudes $[6,16,56]$. Therefore, whereas the gold industry continues to be a valuable source of income to Ugandans, there is need to blend ASGM with environmental conservation [57].

\section{Conclusion and Recommendations}

From this survey, the ecological and livelihood challenges associated with ASGM in Syanyonja definitely span beyond the anticipated benefits. Artisanal gold miners are typically poor, hardworking, illiterate with little or no formal education, under health stresses, malnourished and often somewhat transient. Miners in Syanyonja are better acquainted with the health impacts of the mercury based ASGM than the accompanying environmental impacts. ASGM in Syanyonja have led to deforestation and pollution of land, air and water. Further research should examine the physicochemical and microbiological profile of the water sources utilized by the residents of Syanyonja village, the mercury levels in the blood, hair and urine of the community as well as the atmospheric flux of mercury in this area.

Author Contributions: Authors TO \& SK designed the study and performed fieldwork. Authors SS \& OB organized data and performed the statistical analysis. TO, SK, KMK, OB, RO \& SA wrote the first draft of the manuscript. Authors TO, KMK, \& OB managed the analyses of the study. TO, SK, SS \& SA managed the literature searches. All authors read and approved the final manuscript.

Funding: This research received no external funding.

Acknowledgments: Authors TO, KMK and OB are grateful to the World Bank and the Inter-University Council of East Africa (UICEA) for the scholarships awarded to them through the Africa Center of Excellence II in Phytochemicals, Textiles and Renewable Energy (ACE II PTRE) hosted at Moi University, Kenya.

Conflicts of Interest: The authors declare no conflict of interest.

\section{References}

1. NPA. Second National Development Plan (NDPII). National Planning Authority (NPA), Republic of Uganda. Kampala (UG), 2015. http://npa.ug/wp-content/uploads/NDPII-Final.pdf

2. World Bank. Uganda Overview. http://www.worldbank.org/en/country/uganda/overview 
3. PwC. Uganda Economic Outlook 2017: Q3: July-September 2017.

https://www.pwc.com/ug/en/assets/pdf/economic-outlook-2017-third-edition.pdf

4. Uganda Investment Authority. Mining Sector Profile. 7th November 2016. http://www.ugandainvest.go.ug/index.php/mining

5. Omara, T.; Adupa, E.; Laker, F.; Kalukusu, R.; Owori, T. Potential of Sorghum bicolor L. (Moench) and the Effectiveness of Some Organic Amendments in Remediation of Petroleum-Oil Vitiated Soils of an Automobile Repair Workshop in Urbanite Kampala. Asian J. Appl. Chem. Res. 2019, 3(1), 1-10.

6. Omara, T.; Karungi, S.; Kalukusu, R.; Nakabuye, B.V.; Kagoya, S.; Musau, B. Mercuric Pollution of Surface Water, Superficial sediments, Nile Tilapia (Oreochromis nilotica Linnaeus 1758 [Cichlidae]) and Yams (Dioscorea alata) in Auriferous Areas of Namukombe Stream, Syanyonja, Busia-Uganda. PeerJ 2019, 7 : e7919.

7. Hinton, J.; Kabongo, I.; Kabiswa, C.; Okedi, J.; Mbabazi, R. The Mining and Mineralization Sector in Karamoja Region: Development Opportunities and Constraints. Ecological Christian Organization (ECO), 2011. ISBN 9789970405008.

8. Nyakecho, C.; Hagemann, S.G. An Overview of Gold Systems in Uganda. Aust. J. Earth Sci.2014,61(1), 1-30.

9. Mbonimpa, A. The Genesis and Characteristics of the Gold Mineralisation in the Area Between River Malaba and River Solo in Busia district, South Eastern Uganda. MSc Dissertation, Makerere University, Uganda, 2005.

10. United Nations Environment Programme (UNEP). Analysis of Formalization Approaches in the artisanal and Small-Scale Gold Mining Sector Based on Experiences in Ecuador, Mongolia, Peru, Tanzania and Uganda. Uganda Case study, June 2012.

https://wedocs.unep.org/bitstream/handle/20.500.11822/11357/Formalization_Document_Final_June_2012 .pdf? sequence $=1 \&$ isAllowed $=y$

11. Mallongi, A.; Parkpian, P.; Pataranawat, P.; Chinwetkivanich, S. Mercury Distribution and its Potential Environmental and Health Risks in Aquatic Habitat at Artisanal Buladu Gold Mine in Gorontalo Province, Indonesia. Pak. J. Nutr. 2015, 14(12), 1010-2025.

12. Patricio, C.; Velasquez-Lopez, Veiga, M.M.; Hall, K. Mercury Balance in Amalgamation in Artisanal and Small-scale Gold Mining: Identifying Strategies for Reducing Environmental Pollution in PortoveloZaruma, Ecuador. J. Cleaner Prod. 2009, 18(3), 226-232.

13. Action Coalition Climate Change (ACCC). Status and Extent of Mercury-use by Artisanal and Small-Scale Gold Miners in Selected Gold Mining Sites of Mubende and Busia Districts, Uganda. Research Paper No. 1, 2018, Kampala, Uganda. http://accc-u.org/wp-content/uploads/2018/08/ACCC-REPORT-ONMERCURY-2018-min.pdf

14. Elias, C.; Deborah, S.K.T.; Dewey, D.; Davey, M.; Ngallaba, S.E.; Konje, E. A Cross-Sectional Survey on Knowledge and Perceptions of Health Risks Associated with Arsenic and Mercury Contamination from Artisanal Gold Mining in Tanzania. BMC Publ. Health. 2003, 13(74), 8.

15. COWI. Country Reports on Mercury Trade and Use for ASGM. Appendix to the Report "Mercury Trade and Use for ASGM in Sub-Saharan Africa". 2016. http://cegemi.com/wp-content/uploads/2016/02/MercurySub-Saharan-Africa-Trade-Report-12-December.pdf

16. United Nations Environment Programme. Global Mercury Assessment 2013: Sources, Emissions, Releases and Environmental Transport; UNEP: Geneva, Switzerland. 2013. https://www.zaragoza.es/contenidos/medioambiente/onu/942-eng.pdf

17. Appleton D, Drasch G, Böese-O'Reilly S, Roider G, Lister R, Taylor H, et al. The GEF/UNDP/UNIDO Global Mercury Project - Environmental and Health Results from a Small-Scale Gold Mining Site in Tanzania. 2005. https://core.ac.uk/download/pdf/8793728.pdf

18. Ngabiirwe, W.; Tumwesigye, R.B.; Muloopa, H.B. Human Rights Status in the Gold Supply Chain of Uganda: A Case for Artisanal Small-Scale Mining in Karamoja Region. Global Rights Alert. December 2012. https://www.globalrightsalert.org/sites/default/files/Assessment_of_HR_SSChain_\%20of_\%20Minerals_\%20A_case_\%20ASM_\%20in_Karamoja\%20.pdf

19. Barreto, M.L.; Schein, P.; Hinton, J.; Hruschka, F. Understanding the Economic Contribution of Small-scale Mining in East Africa covering Kenya, Rwanda, and Uganda. Economic Contributions of Artisanal and Small-Scale Mining in Uganda: Gold and Clay. January 2018. http://www.responsiblemines.org/wp-content/uploads/2018/03/Uganda_case_study.pdf

20. Aljazeera, 19th July 2019. Uganda's Gold Boom Leaves Small-Scale Miners Behind. https://www.aljazeera.com/ajimpact/uganda-gold-boom-leaves-small-scale-miners-190719030225658.html 
21. Global Rights Alert. Working conditions of women in mining. A case of Buhweju and Mubende gold mining sites.

https://www.globalrightsalert.org/sites/default/files/The\%20Plight\%20of\%20Women\%20in\%20Gold\%20 Mining\%20in\%20Uganda\%2C\%20a\%20case\%20of\%20Bubende\%20and\%20Buhweju\%20districts.pdf

22. Daily Monitor, Monday July 9th 2018. Women Exploited in Buhweju Mines. https://voice.global/assets/2019/03/The-women-who-toil-in-Buhwejus-gold-pits.pdf

23. Minamata Cop 1: Brief on Mercury and Artisanal and Small-Scale Gold Mining (ASGM). August 2017. https://ipen.org/sites/default/files/documents/print-EN-ipen-brief-asgm-v1_1-en.pdf

24. Obase, R.; Ngoran, G.; Nde, F.; Henry, L.; Ngwane, G. Impact of Artisanal Gold Mining on Human Health and the Environment in the Batouri Gold District, East Cameroon. Acad. J. Interdis. Stud. 2018, 7(1), $25-44$.

25. World Health Organization. Artisanal and Small-Scale Gold Mining and Health. Technical Paper 1: Environmental and Occupational Health Hazards Associated with Artisanal and Small-Scale Gold Mining. 2016. ISBN 9789241510271.

26. Mostafazadeh, B.; Kiani, A.; Mohamadi, E.; Shaki, F.; Shirazi, F.H. Mercury Exposure of Gold Mining Workers in the Northwest of Iran. Pak. J. Pharm. Sci. 2013, 26(6), 1267-1270.

27. Muheki, S.; Geenen, S. Women In (And Out Of) Artisanal Mining: A Call for Revising Uganda's Draft Mining and Minerals Policy. Analysis and Policy Brief no. 25, November 2017, 6 pp. Institute of Development Policy, University of Antwerp.

28. Risher, J.F.; Amler, S.N. Mercury Exposure: Evaluation and Intervention the Inappropriate Use of Chelating Agents in the Diagnosis and Treatment of Putative Mercury Poisoning. Neurotoxicol. 2005, 26(4), 691-699.

29. Grätz, T. Moralities, Risk and Rules in West African Artisanal Gold Mining Communities: A Case Study of Northern Benin. Res Policy. 2009, 34 (1-2), 12-17.

30. Jaques, E.; Zida, B.; Billa, M.; Greffié, C.; Thomassin, J.F. Artisanal and Small-Scale Gold Mines in Burkina Faso: Today and Tomorrow. In: Small-Scale Mining, Rural Subsistence and Poverty and West-Africa, Hilson GM ed, Practical Action Publishing: Rugby, UK, 2008, 354 .

31. Donkor, A.K.; Bonzongo, J.C.; Nartey, V.K.; Adotey, D.K. Mercury in Different Environmental Compartments of the Pra River Basin, Ghana. Sci. Total Environ. 2006, 368(1), 164-176.

32. Obiri, S.; Dodoo, D.K.; Essumang, D.K.; Armah, F.A. Cancer and Non-cancer Risk Assessment from Exposure to Arsenic, Cadmium and Copper by Resident Adults and Children in the Obuasi Municipality, Ghana. Int. J. Human Ecol. Risk Asses. 2010, 16(3), 651-665.

33. Böse-O'Reilly, S.; McCarty, K.M.; Steckling, N.; Lettmeier, B. Mercury Exposure and Children's Health. World's Worst Pollution Problems Report 2010: Top Six Toxic Threats. Blacksmith Institute/Green Cross, Switzerland. Blacksmith Institute: New York, USA; 201b: pp. 33-38, 2010, 188-189.

34. Böse-O'Reilly, S.; Lettmeier, B.; Matteucci Gothe, R.; Beinhoff, C.; Siebert, U.; Drasch, G. Mercury as a Serious Health Hazard for Children in Gold Mining Areas. Environ. Res. 2008, 107(1), 89-97.

35. Gibb, H.; O'Leary, K.G. Mercury Exposure and Health Impacts Among Individuals in the Artisanal and Small-Scale Gold Mining Community: A Comprehensive Review. Environ. Health Perspect. 2014, 122(7), 667672.

36. Ministry of Energy and Mineral Development. Energy and Mineral Development Joint Sector 2012: Ministry of Energy and Mineral Development. Kampala: MEMD, 2012, pp. 48-49.

37. Daily Monitor. Thursday, February 28th, 2019. Miners warned on use of mercury. https://www.google.com/amp/s/www.monitor.co.ug/News/National/Miners-warned-onusemercury/688334-5002504-view-asAMP-7gdbdgz/index.htm.

38. Lacerda, L.D. Global Mercury Emissions from Gold and Silver Mining. Water Air Soil Pollut. 1997, 97, 209221.

39. Oyarzun, R.; Lillo, J.; Higueras, P.; Oyarzùn, J.; Maturana, H. Strong Arsenic Enrichment in Sediments from the Elqui Watershed, Northern Chile: Industrial (Gold Mining at El Indio - Tambo district) Vs. Geologic Processes. J. Geochem. Expl. 2004, 84(2), 53-64.

40. Omara, T.; Nassazi, W.; Adokorach, M.; Kagoya, S. Physicochemical and Microbiological Quality of Springs in Kyambogo University Propinquity. OALib J. 2019, 6, e5189.

41. Haruna, R.; Ejobi, F.; Kabagambe, E.K. The Quality of Water from Protected Springs in Katwe and Kisenyi Parishes, Kampala City, Uganda. Afr. Health Sci. 2005, 5, 14-20.

42. Lukubye, B.; Andama, M. Bacterial Analysis of Selected Drinking Water Sources in Mbarara Municipality, Uganda. J. Water Res. Protect. 2017, 9, 999-1013. 
43. Munabi, C.; Kansiime, F.; Amel, A. Variation of Water Quality in Kakira Catchment Area, Jinja- Uganda. Phys. Chem. Earth Part A/B/C. 2009, 34, 761-766.

44. Kasozi, K.I.; Namubiru, S.; Kamugisha, R.; Eze, E.D.; Tayebwa, D.S.; Ssempijja, F.; et al. Safety of Drinking Water from Primary Water Sources and Implications for the General Public in Uganda. J. Environ. Publ Health. 2019, Article ID 7813962, 12 p.

45. Semuyaba, A.S.; Segawa, I.; Wamala, A. Potential Risk of Lead Toxicity from Bottled Water in Uganda. Mak. Pharm. J. 2014, 12(1), e13-20.

46. National Environment Management Authority (NEMA). National State of Environment Report for Uganda: Harnessing our Environment for Wealth Creation, Uganda. 2012, pp. 107-108.

47. New Vision, 31st July 2013. Museveni Stops Gold Mining in Buhweju. https://www.newvision.co.ug/new_vision/news/1327912/museveni-stops-gold-mining-buhweju

48. NAPE. Small-scale Gold Miners, Government Decry Poor Disposal of Mercury in Mining. http://www.nape.or.ug/news-events/latest-news/45-small-scale-gold-miners-government-decry-poordisposal-of-mercury-in-mining

49. Omara, T.; Ogwang, R.; Ndyamuhaki, S.; Kagoya, S.; Kigenyi, E.; Musau, B.; et al. Spectroscopic Analysis of Selected Priority Trace Metals in the Extant East African Gilled Lungfish (Protopterus amphibius) in Lira Municipal Lagoon and Its Edibility Health Risk. Sci. J. Anal. Chem. 2018, 6(5), 38-45.

50. Omara, T.; Kigenyi, E.; Laker, F.; Adokorach, M.; Otim, G.; Kalukusu, R.; et al. Effects of Continuous DeepFat Frying on the Physicochemical Properties of Assorted Brands of Edible Cooking Oils Sold in Greater Metropolitan Kampala. Asian J. Appl. Chem. Res. 2019, 3(2), 1-13.

51. Tucker, B.W. Overview of Current Seafood Nutritional Issues: Formation of Potentially Toxic Products. In: Shahidi, F.; Jones, Y.; Kitts, D.D. (Eds.), Seafood Safety, Processing and Biotechnology. Technomic Publishing Co. Inc., Lancaster, PA (USA), 1997.

52. Omara, T. Antibacterial Activity of Papain Hydrolysates of Isoelectrically-Isolated Casein and Thermoprecipitated Alpha-Lactalbumin from Bovine and Caprine Milk on Diarrheagenic Bacteria. J. Adv. Med. Life Sci. 2019, 7(3), 1-6.

53. Ogwok, P.; Muyonga, J.H.; Sserunjogi, M.L. Pesticide Residues and Heavy Metals in Lake Victoria Nile perch, Lates niloticus, Belly Flap Oil. Bull. Environ. Contam. Toxicol. 2009, 82(5), 529-533.

54. Birungi, Z.; Masola, B.; Zaranyika, M.F.; Naigaga, I.; Marshall, B. Active Biomonitoring of Trace Heavy Metals Using Fish (Oreochromis niloticus) as Bioindicator Species. The Case of Nakivubo Wetland Along Lake Victoria. Phy. Chem. Earth Parts A/B/C. 2007, 32(15-18), 1350-58.

55. Houdet, J.; Muloopa, H.; Ochieng, C.; Kutegeka, S.; Nakangu, B. Cost Benefit Analysis of the Mining Sector in Karamoja, Uganda. Kampala, Uganda: IUCN Uganda Country Office. 2014; ix +82p. 978-2-8317-1657-2.

56. Djibril, K.N.G.; Tah Bong, C.; Pierre, W.; Magha, A.; Chianebeng, J.K.; et al. Artisanal Gold Mining in Batouri Area, East Cameroon: Impacts on the Mining Population and Their Environment. J. Geol. Mining Res. 2017, 9(1), 1-8

57. Omara, T.; Othieno, N.; Obonge, J.; Ssebulime, S.; Kansiime, M. Characterization and Prognostication of Wastes Generated by Industries in Kampala Industrial and Business Park-Namanve. OALib J. 2019, 6, e5189 